\title{
APROXIMACIÓN SEMIOLÓGICA DE LOS PERSONAJES ORIGINARIOS DEL CARNAVAL DE BARRANQUILLA. EL CONGO, LA MARÍA MOÑITOS, LA MARIMONDA, EL MONOCUCO Y EL GARABATO
}

SEMIOLOGICAL APPROACH TO THE ORIGINATING CHARACTERS OF THE CARNAVAL DE BARRANQUILLA. CONGO, MARIA MOÑITOS, MARIMONDA, MONOCUCO AND GARABATO

\author{
FECHA DE RECIBO: JUNIO 6, 2012 \\ FECHA DE ACEPTACIÓN: JUNIO 24, 2012 \\ KETTY MIRANDA OROZCO
}

Diseñadora gráfica egresada de la Universidad Autónoma del Caribe en Barranquilla y de la Universidad Jorge Tadeo Lozano de Cartagena. Coordinadora de Investigación y docente de tiempo completo del Programa de Diseño Gráfico en la Universidad Autónoma del Caribe. Co-Investigadora del Grupo de Investigación Ellipsis.

\section{RESUMEN:}

Según Canclini (2004), la cultura es el "conjunto de procesos sociales de producción, circulación y consumo de la significación en la vida social", es una puesta en escena de valores simbólicos, es decir, que la cultura produce los significados de las cosas, los hace circular en una sociedad que los consume y reactualiza. Es así como el Carnaval de Barraquilla es un lugar de encuentro y expresión de la simbología de la vida cotidiana del hombre del Caribe colombiano. El presente texto integra reflexiones semiológicas sobre el significado de algunos de los personajes originarios de estas festividades, de tal manera que se muestre la naturaleza de sus significantes.

\section{PALABRAS CLAVE:}

Identidad, cultura, Carnaval, signo, semiología, Diseño Gráfico.

\section{ABSTRACT:}

According to Canclini (2004), culture means a "set of social processes of production, circulation and consumption of signification within social life", it's a staging of symbolic values. Culture produces the meaning of things, makes them circulate in the society that consumes and reenacts them. This is how the Carnaval de Barranquilla becomes a place of encounter and expression of the symbolism of the everyday life of Caribbean people in Colombia. This text integrates semiological reflections about the meaning of some of the original characters of these festivities, in such a way that the nature of their significances is shown.

\section{KEYWORDS:}

Identity, culture, Carnival, sign, semiotics, Graphic Design. 
a cultura es una puesta en escena de valores simbólicos, noción que según la Real Academia de la Lengua Española se define como el conjunto de manifestaciones en que se expresa el 'Heist' ${ }^{\prime}$ o la vida tradicional de un pueblo. Manifestaciones como costumbres, objetos, códigos, indumentaria, creencias y rituales etc, hacen parte de este rubro identitario donde a esta definición se le añade un "conjunto de procesos sociales de producción, circulación y consumo de la significación en la vida social" ${ }^{\prime 2}$. Es decir, que la cultura produce los significados de las cosas y los hace circular en una sociedad que los consume y reactualiza.

El Carnaval es una celebración popular que marca el inicio de la cuaresma. Tuvo origen probablemente en fiestas paganas, como las que se realizaban en honor a Baco, el dios del vino. Estas fiestas, se depuraron durante el Imperio Romano extendiéndose así por toda Europa. Al llegar los españoles al Caribe suramericano, trajeron con ellos costumbres, rituales, danzas y expresiones que se convirtieron en lo que hoy se conoce como los carnavales; una de las expresiones culturales populares que rebosa de significación. Referentes de ello son los carnavales de Río, Venecia y Barranquilla que aluden como protagonistas representativos.

“El Carnaval de Barranquilla es la fusión de una triple herencia (europea, africana y americana), en la que las festividades traídas por los españoles, originadas en arcaicos ritos precristianos del Viejo Mundo, se combinaron con ceremoniales aborígenes y ritos seculares africanos [...] es un lugar de encuentro y expresión de la simbología de la vida cotidiana del hombre del caribe colombiano, cumple la función cultural de permitir la reafirmación de su identidad colectiva e individual, a través de la asimilación de nuevas formas de expresión enmarcadas en códigos culturales universales." ${ }^{3}$

A partir de 1886, y hasta hoy, el Carnaval de Barranquilla se instituye como espacio de encuentro de las manifestaciones culturales del Caribe colombiano, donde se dan cita las creaciones coreográficas y musicales de los pueblos precolombinos americanos, las comparsas y disfraces de origen español y africano que datan del siglo XVI y donde se evidencia la presencia de las culturas árabe (sirios y libaneses), asiática (chinos), hebrea y europea (alemanes, francesas, ingleses, italianos) fruto de posteriores migraciones reci-

Aclaración: el espíritu del pueblo. Eclecticismo de valores, costumbres y tradiciones de un lugar.

2 CANCLINI, Nestor, Laberintos de sentido. Ed. Gedisa Barcelona: 2004.

7 Ministerio de cultura de Colombia. Rescatado el día 20 de diciembre de 2011. De www.carnavaldebarranquilla.org bidas a finales del siglo XIX. ${ }^{4}$ Hoy, las fiestas se inician el sábado con la "Batalla de Flores", un desfile presidido por la reina del Carnaval escogida anualmente, en el que participan carrozas y le siguen a pie las danzas, comparsas, cumbias y disfraces individuales. El domingo, se realiza la Gran Parada de Tradición, en la que nuevamente la reina desfila durante todo el recorrido, seguida por diversas comparsas como la Danza del Paloteo, La Danza de los Coyongos entre otros. El lunes se desarrolla el Desfile de Fantasía, una bella muestra de color, lujo y baile, y el último día, antes del Miércoles de Ceniza, Joselito, personaje representativo, muere para acabar el Carnaval y volver a revivir el próximo año.

El proyecto "Signos y Símbolos del Carnaval de Barranquilla" pretende, desde este último, estudiar los signos, códigos, significados y significantes de los rituales y vestimentas de personajes originarios de la región, como lo son El Congo, La María Moñitos, La Marimonda, El Monocuco, Los Diablos Arlequines y El Garabato. Los sistemas de signos ayudan al ser humano a condicionar la percepción y su comportamiento. "Los signos y símbolos tienen la capacidad de significar cosas ausentes, que no están ellas mismas en el mensaje - sino significadas" ${ }^{\prime \prime}$, son portadores de significados y como productores de conocimiento, edifican la idea que las personas se hacen del mundo. Una aproximación semiológica podría dar a conocer el sentido significativo que estos actores, en su entorno carnestoléndico, tienen ocultos e inmersos y están conjugados en la esencia de sus significantes.

Los signos, las señales y el lenguaje como vehículos de comunicación encierran elementos culturales que influyen en los comportamientos sociales. La Semiología, según Roland Barthes, es una disciplina que entiende que los seres humanos se comunican no solamente a través de los signos lingüísticos, sino también de otros elementos culturales tales como la ropa, el peinado, los gestos, la imágenes, las formas y los colores a fin de convencer a sus protagonistas respecto de las emociones, valores e imágenes que se desean construir. La cultura se puede ver como una forma de producción e interpretación de significados. Las fiestas son un claro ejemplo de esto, ya que muestran todo ese legado cultural y simbólico que las caracterizan y las hacen únicas ante una sociedad.

El Carnaval de Barranquilla se asemeja a lo que en teatro se conoce como farsa y se define como una obra dramática de carácter satírico cuya estructura y trama están basadas en situaciones en que los personajes se comportan de manera extravagante y exagerada, aunque por lo general mantienen una cuota de credibilidad. Su finalidad es

Ministerio de cultura de Colombia. Rescatado el día 20 de diciembre de 2011. De www.carnavaldebarranquilla.org 
entretener y hacer reír al público, con la intención de que se capte una realidad evidente, muchas veces criticando situaciones de tipo social.

En este carnaval se ve como algunas de las danzas y disfraces son el resultado de una crítica a la sociedad o el reflejo de ella misma. Parte de la indumentaria de sus personajes es propia de la vida cotidiana de hombres y mujeres del caribe colombiano: sombrero, calzado (cotizas y sandalias de los campesinos), hoz y machete (instrumentos de labor en el campo), mochilas (bolsos) o evocan antiguas formas de vestir ya desaparecidas en la región ${ }^{6}$. Esta vestimenta es utilizada en las comparsas y los diversos personajes en la configuración de sus disfraces. El disfraz es un artificio que sirve para cambiar el aspecto de una persona a tal punto que simula ser otro. Le permite expresarse de forma espontánea, desinhibirse y ocultar su género, su rol en la sociedad e incluso su nacionalidad, muchas veces para mostrar su verdadero ser y disfrutar de estas fiestas plenamente.

En la configuración de la vestimenta de alguno de los personajes como El Garabato, El Congo y La Muerte se observa la decoración de sus rostros que rara vez es arbitraria y reflejan una inscripción exacta de su relación con la sociedad. La interpretación libre del dibujo dentro del marco de la cara expresa su identidad individual. Esta forma de pintar la cara, denominada "representación partida", incorpora la naturaleza dual del ser humano, que tiene tanto personalidad social como individual. Un rostro sin pintar es mudo. La cara pintada divide la entidad "muda", puramente biológica de la persona social, confiriéndole dignidad humana y significado espiritual. Es literalmente una máscara.

Los disfraces del Carnaval de Barranquilla, de forma histriónica, reflejan en estas festividades acontecimientos tanto antiguos como recientes vividos por sus habitantes. Esta actitud burlesca con la que la sociedad enfrenta el Carnaval es debido a que Barranquilla es una ciudad signada por la inmigración, lo que le ha permitido desarrollar un diverso y complejo tejido social y cultural en donde la interacción de forma respetuosa entre grupos humanos de distintas culturas, ha sido posible debido al espíritu abierto de sus habitantes y al hecho de que este es el principal elemento de cohesión social. Los personajes representativos del Carnaval son un reflejo de la sociedad. Se observan personajes ancestrales como El Congo, que es una representación de antiguas tribus guerreras africanas que llegaron al Caribe. Se observa en el disfraz la presencia de signos de origen español como la capa, la pechera y la penca; y significantes africanos como el rostro pintado, el turbante y las trenzas. A través de este disfraz se muestra su mundo simbólico, sus creencias y valores religiosos y los

Ministerio de cultura de Colombia. Rescatado el día 20 de diciembre de 2011. De www.carnavaldebarranquilla.org diversos conflictos a los que se enfrentaban, como negociar y adaptarse a las reglas del sistema esclavista americano para no perder completamente sus memorias ancestrales. Habla de una fusión de culturas, de esa mezcla triétnica de españoles, africanos e indígenas.

Las personas en el Carnaval se disfrazan, para divertirse y desinhibirse, representando todo tipo de personajes y animales, tanto nativos como exóticos, que son propios y habituales de la celebración. Hay muchos personajes dentro de esta festividad; uno de ellos María Moñitos, que es un hombre vestido de mujer y fue creado por Emil Alfonso Castellanos Calderón (q.e.p.d). Su disfraz está compuesto por signos como la peluca de colores, vestido corto ajustado, una muñeca, el maquillaje extravagante y un beso en la mejilla. En el Carnaval, este personaje de apariencia sexy, persigue a los hombres, se burla de ellos y así obtiene beneficio económico para su hija. Este personaje aparece como símbolo de la irresponsabilidad del hombre ante la manutención de sus hijos, el creciente número de mujeres cabeza de familia y el incremento de la pobreza de las familias, problemáticas del contexto social de la ciudad de Barranquilla y una realidad nacional que se presenta en las clases sociales bajas.

Otro de los actores festivos más representativos del Carnaval de Barranquilla es la Marimonda. Este es un personaje nacido en esta ciudad y creado por el auténtico "mamador de gallo"7 barranquillero que a su vez es un "man llevao" , condición que lo hace un resentido social ante las personas que tienen dinero y que pueden tener, lo que él no puede.

Muchos espectadores creen que este personaje es sinónimo de recocha, desorden y mamadera de gallo; también que su papel es solo el de alegrar y hacer gozar a las personas que están a su alrededor. Más allá de su personalidad particular, la Marimonda tiene una cantidad de significantes que hacen parte de la configuración perteneciente a su indumentaria que hace alusión a situaciones que se viven en la sociedad.

Su disfraz está compuesto por diferentes signos, que logran mostrar la problemática económica de ese momento; entre los que se encuentran: la máscara, la corbata, el pito (llamado "pea pea"), el chaleco y el pantalón al revés. Estos elementos a nivel denotativo no son más que una representación explícita de lo que cada uno es, por ejemplo: la máscara estaba hecha con una funda de almohada, unas orejas de cartón, unos rodillos de boca y una nariz larga; pero a nivel connotativo, esta era utilizada como un medio de expresión para las clases menos favorecidas, puesto que las orejas llevaban grafitis, frases o dichos que burlaban o criticaban a ciertas personas de la élite y su

Aclaración: Jerga barranquillera que se utiliza como sinónimo de gracioso o tomador de pelo.

- Aclaración: Persona de escasos recursos cuya forma de vivir tiende a caer en la miseria. 
ARTE \& DISEÑO, ISSN: 1692-8555, Vol. 10 Núm. 1, Enero - Junio de 2012 KETTY MIRANDA OROZCO

nariz daba un aspecto vulgar y plebe que reflejaba al simio llamado marimonda.

Por otro lado está la corbata, esta es vista como un accesorio de uso masculino que era común dentro de las personas de estratos altos, reflejando elegancia y poder. Dentro de la Marimonda, ésta simboliza una protesta a todas las "corbatas" que han existido en el gobierno, esos puestos fantasmas que se crean para emplear a los familiares de la persona que está a cargo y que ganan grandes sumas de dinero. El pito llamado "pea pea", hace alusión a sonidos flatulentos y con este se puede molestar a las personas que se le acercaban. Apartándose del concepto denotativo, la representación psíquica que tiene el pantalón y la chaqueta al revés es la de mostrar la desigualdad económica que vivían las clases bajas en esa época. Actualmente, sigue con su colorido inconfundible, bailan de cuatro en cuatro en forma de tren y se tiran al suelo haciendo "la canoa". Es bueno resaltar que la palabra "marimonda" es utilizada en la jerga local y su significado depende del contexto en el que se encuentre y que en esta época es bien vista por las personas que son partícipes de estas fiestas, porque ven a este actor festivo como un distintivo de mucha diversión y alegría que ameniza el ambiente en donde se encuentra.

Dentro del Carnaval de Barranquilla se encuentra un personaje muy auténtico, conocido como el Monocuco. De éste se derivan la expresión del argot popular: “¿Cómo estás? mono ${ }^{9}$, monocuco", y el estribillo parroquial: "Monocuco guayabero saca presa del caldero, toma leche y embustero". Tuvo sus comienzos como disfraz individual, pero con el tiempo fue formando comparsas. Su vestuario es muy peculiar porque fue creado para cubrir de pies a cabeza todo el cuerpo de la persona que lo porte. "El Monocuco" es el disfraz del individuo que quería ocultar su identidad y se comenzó a utilizar cuando la gente de la alta sociedad decidió participar en la fiesta del Dios Momo. Se cuenta que muchas personas importantes, serias y conspicuas, ciudadanos de prestancia en el poblado introdujeron con cierta malicia la prenda para poderse divertir a sus anchas sin que las lenguas del pueblo los tomaran para sus retozos de chismografía ${ }^{10}$.

En la configuración de su disfraz, el Monocuco lleva diferentes significantes; entre los que están: la bata con capuchón, los cascabeles, el antifaz, la varita, su hablado afónico y el anonimato. La bata con capuchón la llevaban para pasar desapercibidos ante las personas, lo que hace alusión a los verdugos de la inquisición. El antifaz hace alusión al misterio y a la forma de ocultar la identidad de quien lo porta, puesto que lo llevan para que no puedan

- Aclaración: Mono" es una expresión que en la costa significa "bien o bueno"

12 REDONDO, B. (1999). Monocuco la alegría del Carnaval. [Periódico en línea]. Disponible en: http://www.eltiempo.com/archivo/documento/ MAM-868963. Recuperado Marzo 1 de 2011 ver su rostro y así la gente no reconozca los rasgos físicos de quien esté disfrazado. Otro de los significantes que hace parte del vestuario es la varita; esta es utilizada para alejar a las personas que tratan de reconocerlos, sin pegarles y sin hacerles daño. "Nada mejor que ponerse un capuchón para gozarse a los amigos, a los familiares y hasta a las autoridades, porque el disfraz del Monocuco no es más que eso: una mamadera de gallo" ${ }^{11}$.

A través de los disfraces y comparsas que año tras año se encuentran en el Carnaval de Barranquilla se pueden observar un sinnúmero de acontecimientos del pasado y del presente de la sociedad, ellos son un reflejo burlesco y macondiano de los sucesos mas importantes que ocurren durante un año; la realidad política, social y cultural del país. Es una sátira del mundo; es la exposición de la sociedad, el ciclo de la vida y la muerte.

\section{REFERENCIAS BIBLIOGRÁFICAS}

AMANZU. (Comp). “La cultura y la significación”. Costa Rica. Internet: http://www.scribd.com/amanzu/d/4631895-LACULTURA-Y-LA-SIGNIFICACION

BARTHES Roland. La aventura semiológica. España: Paidós, 2009

CANCLINI. Nestor. Laberintos de sentido. Barcelona: Ed. Gedisa, 2004

CANCLINI. Nestor. Consumidores y ciudadanos. México: Ed. Grijalbo. S.A, 1995

MINISTERIO DE CULTURA DE COLOMBIA. Carnaval de Barranquilla Obra Maestra del Patrimonio Oral e Intangible de la Humanidad. Colombia. Disponible en www.carnavaldebarranquilla.org, Junio 2002

COSTA. Joan. Diseñar para los ojos. Bolivia: Grupo Editorial Design, 2003

OROZC0, M y Soto R. Carnaval Mito y Tradición. Barranquilla: Ediciones Librería Vida, 1997

REDOND0, Bibian. (1999). Monocuco la alegría del Carnaval. [Periódico en línea]. Internet: http://www.eltiempo. com/archivo/documento/MAM-868963. Marzo 1 de 2011

ZECCHETTO, V., Dallera, 0., Marro, M., Braga, M., Vicente, K. Seis semiólogos en busca del lector (3ra ed.). Buenos Aires: La Crujía Ediciones, 2005 